\title{
Needs Asessment of Inclusive Education of Vocational High School in Yogyakarta Haryanto a, Suparno ${ }^{a}$, Deni Hardianto ${ }^{\text {a }}$, Sukinah ${ }^{a}$ \\ ${ }^{a}$ Yogyakarta State University, Karang Malang, Sleman Yogyakarta \\ Corresponding e-mail: suk uny@yahoo.com
}

\begin{abstract}
This study aimed to identifiy the problems faced by schools, principals, teachers in Inclusive Vocational High School, to determine the needs of inclusive Vocational High School in Yogyakarta. This research employed a descriptive method to identify teacher problems in the real context. The data gathered through observing in inclusive Vocational High Schools, interviewing of class teachers and principals and analyzing the document of students with special needs and assessment. The subjects of this study were the class teachers and the headmasters from 10 inclusive Vocational High Schools. The results revealed that $70 \%$ of private inclusive Vocational High Schools independently initiatives to provide services for children with special needs, $30 \%$ of Public inclusive Vocational High Schools appointed by the government provide services to children with special needs. It is identified several needs that are preparing teachers 'knowledge and skills, developing teachers' skills in assisting children with disabilities in inclusive classes, requiring the knowledge of inclusive education, identifying and assessing children with disabilities, developing inclusive setting classroom management model, arranging individual program, arranging accommodative learning program and creating evaluation models that appropriate to the conditions and characteristics of each student. Teachers had difficulties to implement the lesson in which children with special needs involve in. Teachers need guidebooks or modules as a guidance in managing inclusive classes setting in inclusive Vocational High School. Therefore, it is necessary to develop a validated guidebook for assisting children with special needs in inclusive Vocational High School.
\end{abstract}

Keywords: Needs assesment, Inclusive Vocational High School, validated manual book

\section{INTRODUCTION}

Ministry of Social Affairs of the Republic of Indonesia in 2011 shows that the number of children with special needs has reached 7 million people or about $3 \%$ of the total population in Indonesia amounted to 238 million. Most of them are children with slow learner, autistic children, and $60 \%$ of children with intelletual disability. Based on the data, the prior education for children with intellectual disabiliy is aimed to develop life skills $\mathrm{t}$ and motor skills. The data indicates that the total amount of children with special needs in school age in the Special Region of Yogyakarta is 9096 children. There are 4,722 children accommodated in 76 Special Schools in Yogyakarta. On the other side, before Yogyakarta declared as an inclusive education providers area, it has had 400 inclusive schools that can accommodate 2,388 children. So, there are still 1,986 children with special needs who can not access education yet.(WARTAHARIAN.CO-Yogyakarta).

Every citizen has the equal rights in education without discriminating the status and physical condition. Therefore the state must be firm and widely open without any compromise in the education process. This pattern or model of education can be obtained at Vocational High
School (Tarsidi, 2004). Education is the right of every individual including the children with special needs. According to the Law of the Republic of Indonesia Number 20 Year 2003 on National Education System, it has provided new pattern in providing the education for children with special needs. In Clause 32 of the Law on the National Education System states that: "Special education is education for learners who have difficulty in following the learning process because of physical, emotional, mental, social, and / or have potential of intelligence and special talent". The clause provides a breakthrough on the model of educational services for children with special needs in the form of implementing inclusive education.

Inclusive Education has been introduced in Indonesia for several years, but its presence has not yet reached the level of Vocational High School, it's meant that there is no breakthrough to implement the inclusion education at Vocational High School, one of the most difficult challenges faced by Vocational Hogh School is about the readiness of school members, inclusive education management, regular teacher understanding in teaching special needs students in order to develop inclusive learning in the classroom and providing socialization to regular students about how to address the presence of special needs students in their school. (Yachya 
Hasyim, 2013). The study results of Jenny Rinty's (2010) in Bandung showed that $62.5 \%$ of special teachers were less confident in their abilities, sometimes they were less sure whether they were able to face difficulties when assisting children and able to survive to assist the child with special needs. There are several services for children with special needs aimed to find out the barriers experienced by children and to utilize their potency to access life opportunities as wide as possible (Hallahan and Kauffman, 2006)

This study aims to map the types and characteristics of children with special needs in inclusive Vocational High School, to identify problems faced by classroom teachers in assisting children with special needs, and to know the readiness of classroom teachers to assist children with special needs in joining the learning process in the classroom.

\section{METHOD}

The research approach of this study is descriptive quantitative research with survey method. Research subjects were 150 regular teachers who had students with special needs from 10 inclusive vocational schools in Yogyakarta. The purposive sampling technique used in this study was employed by taking data on subjects who have assisted students with special needs. The data was collected by questionnaires. The quantitative data were analyzed descriptively.

\section{RESULT AND DISCUSSION}

Data of types of children with special needs who join in inclusive vocational school in Yogyakarta:

Table 1. Types of Special Needs and Number of Students in inclusive vocational high school

\begin{tabular}{|c|c|c|c|}
\hline No & $\begin{array}{c}\text { Type of } \\
\text { Special need } \\
\text { Children }\end{array}$ & Total & Description \\
\hline 1. & $\begin{array}{l}\text { Childen with } \\
\text { Visual } \\
\text { Impairment }\end{array}$ & 3 & $\begin{array}{l}\text { - This data is tentative } \\
\text { because in some school } \\
\text { there is no student with }\end{array}$ \\
\hline 2. & $\begin{array}{l}\text { Children with } \\
\text { Hearing } \\
\text { Impairment }\end{array}$ & 20 & $\begin{array}{l}\text { special needs. } \\
\text { - Unearned data of } \\
\text { students with behavioral, }\end{array}$ \\
\hline 3. & $\begin{array}{l}\text { Children with } \\
\text { Intellectual } \\
\text { Disability }\end{array}$ & 6 & $\begin{array}{l}\text { emotional and social } \\
\text { disorders in all schools. } \\
\text { - Unidentified children }\end{array}$ \\
\hline 4. & Slow Learner & 16 & with behavior disorder, \\
\hline 5. & $\begin{array}{l}\text { Children with } \\
\text { Physical }\end{array}$ & 3 & $\begin{array}{l}\text { slow learner due to the } \\
\text { lack of knowledge, skills, }\end{array}$ \\
\hline
\end{tabular}

\begin{tabular}{cccc}
\hline & Impairment & $\begin{array}{c}\text { in identifying the type of } \\
\text { student with special need. }\end{array}$ \\
\cline { 1 - 2 } 6. & $\begin{array}{c}\text { Autistic } \\
\text { Children }\end{array}$ & 5 & \\
\cline { 1 - 2 } Total & 53 & \\
\cline { 1 - 2 } & &
\end{tabular}

Data collected in identifying difficulties faced by classroom teachers and headmasters of inclusive vocational high school through questionnaires and they filled out it at the assessment identification training held by Dikpora DIY in 2016. The 150 Participants were teachers from inclusive vocational high school in Yogyakarta and there were 131 collected and 19 participants who have not been present in training. The results of the identification of difficulties teachers and principals of SPPI can be summarized in the table 2:

Table 2. The identification of Teacher Difficulties in assisting Students with Special Needs in SMK DIY.

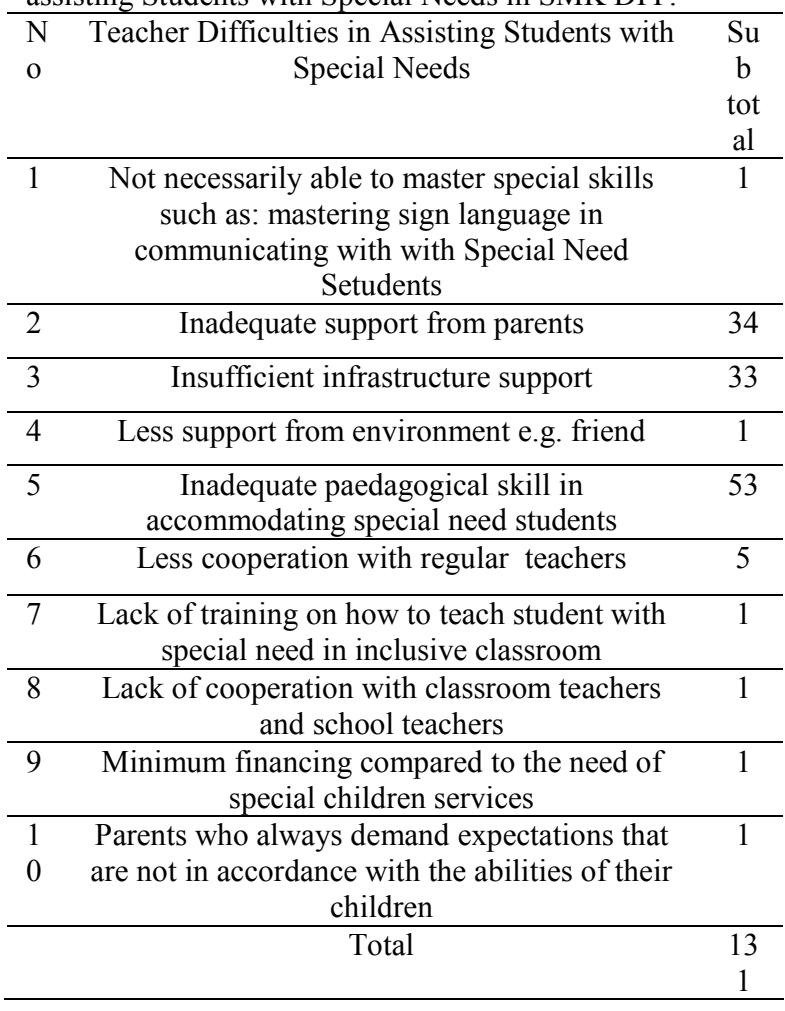

Table 2 shows that most of the difficulties experienced by teachers in the aspect of the teaching ability of children with special needs are not sufficient to accommodate the children as much as 53 respondents. While at least 1 respondent in some aspects include the lack of training on how to assist children with special needs in the classroom, cooperating with classroom teachers, minimum financing compared to the need for special needs services, parents who always demand expectations 
that are not in accordance with the ability of children and not necessarily able to master special skills such as: mastering sign language in communicating with special need student.

The percentage of the results of teacher difficulties identification indicates that $40 \%$ teachers' difficulties in assisting special needs students in inclusive school are inadequate teaching ability of children with disabilities. Based on the identification and assessment of the needs of classroom teachers in accommodating children with special needs, indicates that teachers are still having difficulty in addressing special needs children in inclusive setting classes. Therefore, one of the teachers' expectation is the existence of a manual book or module in assisting student with special needs in the inclusive class in a practical way.

The result of requirement analysis of teacher readiness in assisting children with special needs in SMK :

Table 3 Teachers Readiness

\begin{tabular}{|c|c|c|}
\hline $\begin{array}{l}\mathbf{N} \\
\mathbf{0}\end{array}$ & $\begin{array}{l}\text { Aspec } \\
\text { t of } \\
\text { Teach } \\
\text { er } \\
\text { Requi } \\
\text { reme } \\
\text { nt }\end{array}$ & Description \\
\hline 1 & $\begin{array}{l}\text { The } \\
\text { conce } \\
\text { pt of } \\
\text { inclus } \\
\text { ive } \\
\text { educat } \\
\text { ion }\end{array}$ & $\begin{array}{l}90 \% \text { teachers need of knowledge and concept } \\
\text { of inclusive education that is consistent with } \\
\text { their philosophy. Not only about how to } \\
\text { handle the children with special needs but } \\
\text { accepts all children with no discrimination. }\end{array}$ \\
\hline 2 & $\begin{array}{l}\text { Identi } \\
\text { ficatio } \\
\mathrm{n} \text { and } \\
\text { assess } \\
\text { ment }\end{array}$ & $\begin{array}{l}100 \% \text { of teachers are currently experiencing } \\
\text { difficulties in identifying and assessing } \\
\text { children with disabilities in inclusive schools. } \\
\text { Teachers have a perception that the } \\
\text { identification and assessment was done } \\
\text { during the admission of new students. }\end{array}$ \\
\hline 3 & $\begin{array}{l}\text { Inclus } \\
\text { ive } \\
\text { classr } \\
\text { oom } \\
\text { mana } \\
\text { geme } \\
\text { nt }\end{array}$ & $\begin{array}{l}75 \% \text { of the teachers have difficulty in } \\
\text { managing the class with special needs } \\
\text { students still, especially in referring, as well } \\
\text { as addressing behavior, emotional and social } \\
\text { specific problems. For example: how does a } \\
\text { teacher should handle children who have } \\
\text { aggressive behavior? }\end{array}$ \\
\hline 4 & $\begin{array}{l}\text { Prepar } \\
\text { ation } \\
\text { of } \\
\text { learni } \\
\text { ng } \\
\text { progra } \\
\text { ms }\end{array}$ & $\begin{array}{l}90 \% \text { teachers have difficulty in preparing } \\
\text { regular learning programs but there are } \\
\text { elements that should be modified in the } \\
\text { preparation of inclusive class programs. }\end{array}$ \\
\hline
\end{tabular}

\begin{tabular}{|c|c|c|}
\hline 5 & $\begin{array}{c}\text { Indivi } \\
\text { dual } \\
\text { Educa } \\
\text { tional } \\
\text { Plans } \\
\end{array}$ & $\begin{array}{l}90 \% \text { of teachers have difficulty in making } \\
\text { individual Educational plans in inclusive } \\
\text { classroom settings. }\end{array}$ \\
\hline 6 & $\begin{array}{c}\text { Learni } \\
\text { ng } \\
\text { Progr } \\
\text { am } \\
\text { Plan }\end{array}$ & $\begin{array}{l}75 \% \text { Teachers need skills in modifying an } \\
\text { accommodative learning program plan } \\
\text { according to classroom needs and conditions. }\end{array}$ \\
\hline 7 & $\begin{array}{l}\text { Inclus } \\
\text { ive } \\
\text { Classr } \\
\text { oom } \\
\text { Evalu } \\
\text { ation } \\
\text { Model }\end{array}$ & $\begin{array}{l}80 \% \text { teachers require knowledge and skills } \\
\text { on inclusive class evaluation models that are } \\
\text { appropriate to the characteristics of students } \\
\text { with special needs }\end{array}$ \\
\hline 8 & $\begin{array}{c}\text { Comp } \\
\text { ensato } \\
\text { rist } \\
\text { Progr } \\
\text { am } \\
\text { Devel } \\
\text { opme } \\
\text { nt } \\
\end{array}$ & $\begin{array}{c}90 \% \text { teachers need knowledge and skills in } \\
\text { Compensatorist Program development of } \\
\text { children with disabilities in inclusive class } \\
\text { settings }\end{array}$ \\
\hline 9 & $\begin{array}{c}\text { Devel } \\
\text { oping } \\
\text { media } \\
\text { and } \\
\text { specia } \\
1 \\
\text { faciliti } \\
\text { es }\end{array}$ & $\begin{array}{l}70 \% \text { teachers need the development of media } \\
\text { and specific facilities in inclusive learning } \\
\text { classroom settings and special assistance for } \\
\text { special need students. }\end{array}$ \\
\hline
\end{tabular}

The result of the identification of teacher difficulties in accommodating children with special needs in inclusive classroom in inclusive vocational school showed $70-100 \%$. The lowest difficulty experienced by teachers in media development and special facilities in $70 \%$, while the most difficult is the ability to identify and assess student with special need.

Table 4. The Identification of Lesson Planning Skill Aspect

\begin{tabular}{ccc}
\hline No & $\begin{array}{c}\text { Component of } \\
\text { Learning } \\
\text { Readiness }\end{array}$ & Description \\
\hline 1 & $\begin{array}{c}\text { Learning } \\
\text { Objectives of } \\
\text { operational } \\
\text { materials }\end{array}$ & $\begin{array}{c}90 \% \text { teachers have difficulty } \\
\text { in modifying the formulation } \\
\text { of learning objectives when } \\
\text { there are various students with } \\
\text { special needs in one class. For } \\
\text { example: autistic children, } \\
\text { slow learner, blind also deaf } \\
\text { children. }\end{array}$ \\
& & $\begin{array}{c}100 \% \text { teachers have problems } \\
\text { in describing the forms of } \\
\text { teaching and learning activities }\end{array}$ \\
\hline 2 & The form of & \\
& teaching and \\
learning activities
\end{tabular}




\begin{tabular}{|c|c|c|}
\hline & & $\begin{array}{l}\text { with the various students with } \\
\text { special needs. }\end{array}$ \\
\hline 3 & The method used & $\begin{array}{l}60 \% \text { teachers have difficulty in } \\
\text { determining the method used } \\
\text { in learning process with classes } \\
\text { that have different ability and } \\
\text { condition of student with } \\
\text { special needs }\end{array}$ \\
\hline 4. & Time & $\begin{array}{l}70 \% \text { teachers have difficulty in } \\
\text { sharing the equal time for each } \\
\text { student because the students } \\
\text { have various ability. }\end{array}$ \\
\hline 5. & Learning Tools & $\begin{array}{l}90 \% \text { teachers have difficulties } \\
\text { relating to the provision of } \\
\text { specialized learning tools } \\
\text { appropriate with the needs and } \\
\text { conditions of students }\end{array}$ \\
\hline 6 & $\begin{array}{l}\text { Evaluation of } \\
\text { learning }\end{array}$ & $\begin{array}{l}85 \% \text { teachers have difficulty in } \\
\text { preparing and implementing } \\
\text { evaluation process with various } \\
\text { types of assessment } \\
\text { instruments according to the } \\
\text { conditions of students with } \\
\text { special needs. }\end{array}$ \\
\hline
\end{tabular}

Table 4 shows that approximately $75-80 \%$ teachers in inclusive vocational high school experience difficulties in the preparation of an accommodative learning plan with various students with special needs.

\section{DISCUSSION}

One of the expectations of teachers is the guidance or module in assisting students with special needs in practical inclusive classes. This will become the guidance of teachers to recognize the concept of inclusive education, to understand children with special needs, to identify and assess children with special both academically and non academically, to arrange individual and group learning planning, to implement learning program in inclusive classroom setting, to evaluate learning in an inclusive class setting.

The results showed that $75-80 \%$ of inclusive vocational high school had difficulties in preparing lesson plans. This is appropriate with previous research indicating that when classroom teachers report receiving academic instruction and / or professional development training related to inclusive classes, they still do not feel really ready to teach children with special needs in the setting of inclusive education (DeSimone \& Parmar 2006 ; Ford, Pugach, \& Otis-Wilborn, 2001; Hamre, 2004; Pavri, 2004; Yellin et al., 2003).
Other research results indicate that about $70 \%$ of teachers are seen as having little or no knowledge of teaching students with special needs, and their attitudes are mostly negative. But young teachers experience higher competencies. Furthermore, some teachers who have a positive attitude about inclusive education will not accept students with special needs if they can make choices. Teachers competence in regular schools is not developed equally. The reasons for these findings, in some aspects, can be found in teacher training college programs that have changed in recent decades. According to the results and teachers' personal perceptions conclude that teachers lack of the necessary skills and competencies can be formed.

The results show that regular teacher skills in assisting children with special needs has had difficulty in identifying and assessing children with special need and composing individual learning programs and accommodative learning. The highest skill required by teachers in assisting children with special needs in vocational school is $26 \%$ to identify and assess child with special needs and $24 \%$ to prepare individual learning program. Therefore, based on the results of this study, teachers need practical guidance in assisting children with special needs in inclusive vocational high school so that student with special needs can optimally grow.

Based on literature, regular classroom teachers are the most important variable in the success of the inclusion program (Bhatnagar \& Das, 2013; Das et al, 2013a; Shah, 2005). This is what they do and what they believe establish the quality of instruction that all students (especially those with disabilities) receive in the classroom. The literature on inclusive education also agrees on the fact that no matter how good the educational infrastructure is, how well the educational policy is voiced, how well the resource program, effective inclusion does not occur until regular classroom teachers provide relevant and meaningful instruction for students with disabilities (Das et al, 2012; Mastropieri \& Scruggs, 2000)

Competencies required by regular teachers in these inclusive schools to improve learning services for children with special needs are to carry out the acceptance of new learners who accommodate all children, to implement a flexible and accommodative curriculum, to design teaching materials, to organize child-friendly classes, to provide and use th adaptive learning media, and to conduct learning evaluations in inclusive education settings. 


\section{CONCLUSION}

Based on the results of this study, it is known that:

1. Inclusive vocational school teachers have difficulty in the implementation of learning children with special needs because there is no module book as a guidance for students with special. Therefore, it is necessary to develop a validated module for teacher to assisst students with special need.

2. The module contents for teachers as guidance for special need students inclusive vocational school are the implementation of inclusive education, identification and assessment of children with special needs, preparation of individual learning programs and lesson planning, implementation of learning in inclusive classroom settings and evaluation of learning process in inclusive class settings.

\section{RECOMMENDATION}

Based on this research, there are recommendations for the future study:

1. The classroom teacher needs to have skills in modifying the curriculum and learning method in according to the child's condition.

2. The school principal requires guidance of classroom teachers in accommodating children with special needs

3. The researcher should continue to the next stage until it becomes a validated modul as a guide for classroom teachers in assisting special need students in inclusive vocational high school.

\section{REFERENCES}

[1] Beattie, J. R., Anderson, R. J., \& Antonak, R. F. (1997). Modifying attitudes of prospective educators toward students with disabilities and their integration Das et al., (2012). Inclusive education in India: A paradigm shift in roles, responsibilities and competencies of regular school teachers. Journal of Indian Education.

[2] Das et al., (2013a). Implementing inclusive education in Delhi, India: Regular school teachers' preferences for professional development delivery modes. Professional Development in Education, DOI:10.1080/19415257.2012.747979

[3] Das et al., (2013b). Inclusive education in India: Are the teachers prepared? International Journal of Special Education, 28(1), 27-36.into regular classrooms. The Journal of Psychology, 131(3), 245-
[4] Hallahan, D.P. \& Kauffman, J.M. (2006). Exceptional Learners: Introduction to Special Education 10th ed. USA: Pearson

[5] Jenny Rinty (2010). Studi deskriptif mengenai self-efficacy pada guru pendamping ABK diSD $\mathrm{X}$ bandung. Tesis: Jakarta: Universitas Kristen Maranatha.

[6] Johnsen, Berit H dan Miriam D. Skjorten (2003) Pendidikan Kebutuhan Khusus; Sebuah Pengantar, Bandung : Unipub

[7] Kauffman and Mara Sapon-Shevin.Educational Leadership.52 (4) 7-11 Stainback,W.\& Sianback,S.(1990). Support Networks for Inclusive Schooling:Independent Integrated Education.Baltimore: Paul H.Brooks.

[8] Peraturan Rektor UNY Nomor 1.a Tahun 2012 Tentang Rencana Induk Penelitian Lembaga Penelitian dan Pengabdian Kepada Masyarakat UNY.

[9] UNESCO (1994). The Salamanca Statement and Framework For Action on Special Needs Education.

PARIS:Author.Warnock,H.M.(1978). Special Educational Needs:Report of The committee of Enquiry in the Education of Handicapped Young People. London: Her Majesty's, Stationary Office

[10] Yachya Hasyim, 2013, Pendidikan Inklusif di Sekolah Menengah Kejuruan Negeri 2 Malang Jurnal Kebijakan dan Pengembangan Pendidikan Volume 1, Nomor 2 Juli 2013, ISSN: 2337-7623; EISSN: 2337-7615 